\begin{tabular}{|l|l|l|}
\hline \multicolumn{2}{|c|}{ PublisherInfo } \\
\hline \hline PublisherName & $:$ & BioMed Central \\
\hline \hline PublisherLocation & $:$ & London \\
\hline \hline PublisherImprintName & $:$ & BioMed Central \\
\hline \hline
\end{tabular}

\title{
Meticillin-resistance spread by horizontal gene transfer
}

\begin{tabular}{||l|l|l||}
\hline \multicolumn{2}{|c|}{ ArticleInfo } \\
\hline \hline ArticleID & $:$ & 4101 \\
\hline \hline ArticleDOI & $:$ & $10.1186 /$ gb-spotlight-20010530-01 \\
\hline \hline ArticleCitationID & $:$ & spotlight-20010530-01 \\
\hline \hline ArticleSequenceNumber & $:$ & 172 \\
\hline \hline ArticleCategory & $:$ & Research news \\
\hline ArticleFirstPage & $:$ & 1 \\
\hline \hline ArticleLastPage & $:$ & 2 \\
\hline \hline & $:$ & RegistrationDate : 2001-05-30 \\
ArticleHistory & $:$ & OnlineDate \\
\hline \hline ArticleCopyright & $:$ & BioMed Central Ltd2001-05-30 \\
\hline \hline ArticleGrants & $:$ & \\
\hline \hline ArticleContext & $:$ & 130592211 \\
\hline \hline
\end{tabular}




\section{Tudor Toma}

Email: ttoma@mail.dntis.ro

Meticillin-resistant Staphylococcus aureus (MRSA) bacteria owe their resistance to a penicillinbinding protein with low affinity for antibiotics, encoded by the mecA gene. In a research letter in the May 26 Lancet, Camiel Wielders and colleagues from University Hospital Utrecht, The Netherlands, provide evidence that a new MRSA genotype can emerge in vivo by transfer of the meticillin-resistance gene from one staphylococcal species to another.

Wielders et al. isolated a successive pair of mecA- and mec $\mathrm{A}+\mathrm{S}$. aureus strains from a baby whose initial meticillin-susceptible infection had been treated with $\beta$-lactam antibiotics, and who then subsequently developed an MRSA infection. Although the two $S$. aureus genotypes were almost indistinguishable, the mecA DNA from the MRSA sample was identical to that in a S. epidermidis strain isolated from the same baby (Lancet 2001, 357:1674-1675).

Because this mec $\mathrm{A}+$ genotype was isolated from an infant younger than 2 months who was neither transferred from a different hospital nor in contact with an MRSA carrier, the authors conclude that resistance was acquired by the horizontal transfer of mecA DNA from the $S$. epidermidis strain.

Further evidence from similar cases will be needed to exclude the possibility that the second infection was not picked up from an unknown third person or from the hospital itself.

\section{References}

1. Wielders CLC, Vriens MR, Brisse S, de Graaf-Miltenburg, Troelstra A, Fleer A, Schmitz FJ, Verhoef J, Fluit AC: Evidence for in-vivo transfer of mecA DNA between strains of Staphylococcus aureus. Lancet 2001, 357:1674-1675., [http://www.thelancet.com] 